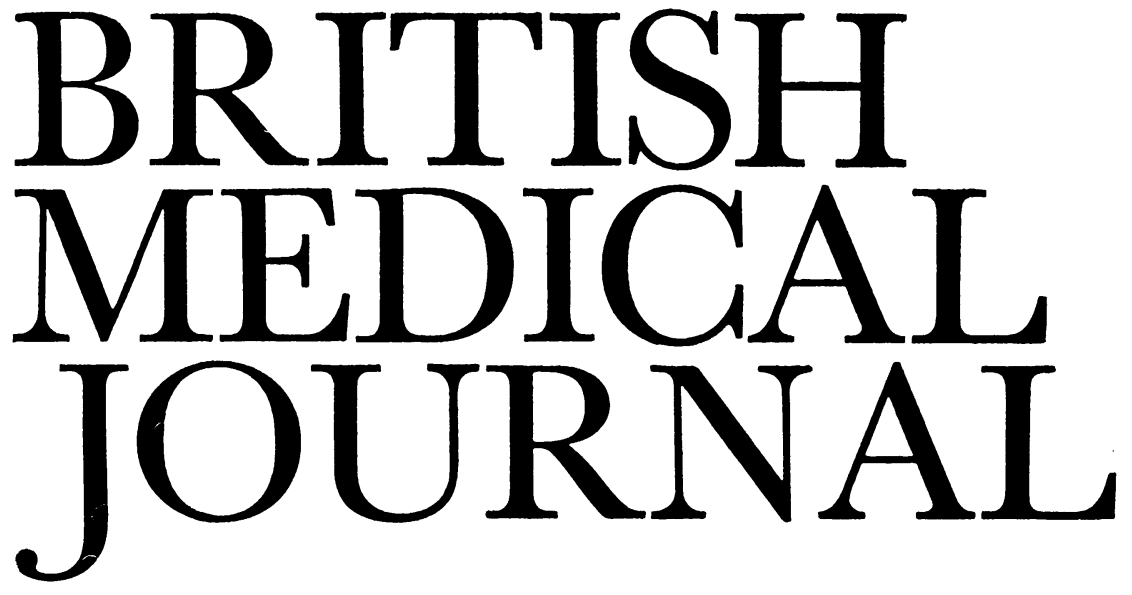

LONDON, SATURDAY 15 OCTOBER 1983

\title{
Recognising and preventing Duchenne muscular dystrophy
}

Rare progressive genetic disorders matter intensely to the families who suffer from them but they cannot figure largely in every doctor's training or experience. Indeed, an interest in such conditions is often regarded as evidence of intellectual elitism and unworthy of practical doctors. When treatment becomes available our attitude changes-for example, in phenylketonuria or congenital hypothyroidism-but the availability of genetic counselling for prevention is more often ignored. The paper by O'Brien, Sibert, and Harper (p 1106) highlights one important example.

Duchenne muscular dystrophy occurs in one in every 3000 males. It is usually overlooked in its early stages, but the distressing consequences of progressive paralysis inexorably handicap the boy and his family over 15-25 years, and the parents never really recover from the experience. They regard the spread of this X linked disease through the family, affecting brothers or the sons of aunts and sisters, as unforgivable, ${ }^{1}$ yet O'Brien et al show just how often this occurs. The two main reasons are late diagnosis and the failure of genetic counselling once the diagnosis is made. Counselling fails not because of the provision of wrong information or the inadequacy of carrier tests (imperfect though they are) but from simple failure of those responsible for the boy to trace and advise the women and girls who are at risk of being carriers. Thus of 155 consecutive cases born in the north of England, 55 might have been prevented by earlier diagnosis in a relative in $24(15 \%)$; better carrier tracing in $28(18 \%)$; better carrier counselling in $2(1.3 \%)$; and better carrier detection methods in $1(0 \cdot 6 \%){ }^{2}$

Late diagnosis is the main factor emphasised by O'Brien et $a l$ and was a potent cause of distress in Firth's study of the experiences of parents of sufferers. ${ }^{1}$ How can affected boys be recognised earlier? Often their development is slow, well before the more obvious clumsiness of gait and falling are noticed. Their average age at learning to walk unsupported is 18 months, ${ }^{3}$ and often their speech development is also delayed. That many affected boys are mildly retarded and especially so in their verbal abilities is a potent factor in delaying recognition because it is so unexpected in a muscle disease. Most boys never learn to run or to hop or jump. They are late in becoming able to climb stairs. The famous Gowers sign-whereby the boy stands from the supine position by rolling over, pushing up on to all fours, and then climbing up his legs-is rarely fully developed before the age of 4 or 5 years. Its carliest feature is usually the roll to the prone position. Formal examination in a young boy may show very little, but as early as 2 years of age some hypotonia at the shoulders (best appreciated by picking him up by the axillae) and early hypertrophy of the calves may be detectable. Whenever parents report that something is wrong with a child's walking the doctor's response should be to watch him in action, running along a corridor, hurrying up stairs, and trying to jump over his shoes.

Once the suspicion of Duchenne muscular dystrophy is there, diagnosis is easy. Apart from laboratory errors the serum creatine kinase activity is always high, 30-300 times normal. Muscle biopsy, always justifiable in an early case, should be done in a centre where skilled handling of the sample and histochemical staining are available.

The problems of helping the family to come to terms with muscular dystrophy and of teaching them enough about it to enable them to plan their lives appropriately are formidable, ${ }^{4} 5$ but this is a necessary prerequisite to giving effective genetic advice to the parents and to the mother's sisters, daughters, maternal cousins, and others. Most families seem to welcome the chance to have their boy and indeed all the facets of the case assessed at a centre with a special interest in muscular dystrophy, and if this is to be done the diagnostic biopsy should perhaps be done there too as soon as possible after the high serum creatine kinase activity is found. The manner in which the diagnosis is presented to them has a critical and often permanent effect on the attitude of the parents to the disease and its management-and to medical services in general. ${ }^{1}$

Early clinical diagnosis is recommended by O'Brien et al as being preferable to neonatal screening. The latter is feasible, ${ }^{2}$ and a pilot study of its efficacy as a means of prevention is being conducted in Edinburgh. ${ }^{6}$ The impact of the news on the parents' attitude to the baby, the effect of genetic counselling on parents when the affected baby looks quite normal, and the cost effectiveness of neonatal screening, unprecedented in an untreatable disease, must all be assessed before the idea is likely to gain widespread official acceptance. In the mean time, however, new families continue to be distressed by delays in diagnosis. The Muscular Dystrophy Group of Great Britain runs local postgraduate conferences but has found, perhaps predictably, that few family doctors attend them. Would 
the repeated postal circulars suggested by O'Brien et al be better received? If muscular dystrophy cannot easily be kept uppermost in the mind of the family doctor who might never encounter a case, screening may be the only way to prevent unacceptable diagnostic delays.

One possible solution is to include clinical medical officers more actively, to permit them to obtain blood samples for creatine kinase assay, and to suggest that they screen all those boys (3\% of the male population) who are (or were) unable to walk at 18 months-plus those who have unexplained motor and speech delay or who are unable to run or jump at 2 years. They might have to test $5 \%$ of boys altogether, but probably the rate of diagnosis would potentially approach that of neonatal screening. The 18 month rule alone would pick up $40-50 \%$ of cases. ${ }^{3}$ Success would depend on a high proportion of children being seen at $1 \frac{1}{2}-2 \frac{1}{2}$ years of age, however, and both health visitors and clinical medical officers might have to rethink the timing and thoroughness of their efforts to recall children for examination if there was developmental delay at this age. Techniques of blood spot testing for whole blood creatine kinase ${ }^{78}$ would mean that only a finger prick or heal prick would be necessary; high results could be checked later with a venous sample. The benefits of giving clinical medical officers access to laboratory screening methods have been disputed, but this is one example where it seems potentially important. Perhaps one or more regional health authorities could pioneer an experimental scheme for comparison with the Edinburgh neonatal screening project and develop the techniques and the lines of referral for expert diagnosis and counselling, which would be essential to the success of such an endeavour. ${ }^{1}$

For the present, however, the responsibility for recognising Duchenne muscular dystrophy in time to prevent a greater family tragedy rests with every doctor who is asked "Why isn't he walking properly ?" The answer requires careful observation of the child in action and the willingness to check the serum kinase activity whenever there is doubt.

\section{DAVID GARDNER-MEDWIN}

Consultant Paediatric Neurologist,

Regional Neurological Centre,

Newcastle General Hospital,

Newcastle upon Tyne NE4 6BE

${ }^{1}$ Firth MA. Diagnosis of Duchenne muscular dystrophy: experiences of parents of sufferers. $\mathrm{Br} \mathrm{Med} \mathcal{F} 1983 ; \mathbf{2 8 6}: 700-1$.

2 Gardner-Medwin D. Controversies about Duchenne muscular dystrophy. (1) Neonatal screening. Dev Med Child Neurol 1979;21:390-3.

3 Gardner-Medwin D, Bundey S, Green S. Early diagnosis of Duchenne muscular dystrophy. Lancet 1978;i:1102.

4 Taft LT. The care and management of the child with muscular dystrophy. Dev Med Child Neurol 1973;15:510-8.

5 Walton JN, Gardner-Medwin D. Progressive muscular dystrophy and the myotonic disorders. In: Walton J, ed. Disorders of voluntary muscle. 4th ed. Edinburgh: Churchill Livingstone, $1981: 481-524$.

- Skinner R, Emery AEH, Scheuerbrandt G, Syme J. Feasibility of neonatal screening for Duchenne muscular dystrophy. $\mathcal{F}$ Med Genet 1982;19: 1-3.

7 Zellweger H, Antonik A. Newborn screening for Duchenne muscular dystrophy. Pediatrics 1975;55:30-4.

${ }^{8}$ Lloyd SJ, Skinner R, Emery AEH. Fluorimetric electrophoretic assay for creatine kinase in dried blood samples. [Abstract.] $\mathcal{f}$ Med Genet 1982; 19:458.

\section{Oncogenes and multistep carcinogenesis}

Spectacular successes always attract criticism, and a legitimate criticism of recent advances in our understanding of the genetics of human cancer has been that they depend on a gross oversimplification of an extremely complex process. It is the simplicity of the approach, in part, that has made it so compelling (simplicity, that is, in principle: in practice it is based on very high technology molecular biology).

The technique is to extract the DNA from tumour cells, cleave it into roughly gene sized pieces, and reintroduce the fragments into cultured mouse cells. Any fragment that induces cancerous changes in the mouse cells may then be presumed to have played a part in the induction of the original tumour. This was the method used by two American research teams, late last year, to incriminate a specific mutant gene in a human bladder carcinoma. ${ }^{12}$ What made the result a landmark in cancer research was the link it established between human cancer and not just one gene but a group of 15 or so that were already implicated in tumorigenesis on other grounds. ${ }^{3}$ The genes in question had originally been identified as the oncogenes responsible for the tumorigenic effects of the RNA tumour viruses of animals; and the possibility of a link with human cancer had only recently come to light with the discovery of homologous genes (proto-oncogenes, as they were called) in normal human cells.

The tumorigenic gene extracted from the bladder carcinoma cells turned out to be a mutant of one of the cellular protooncogenes-specifically, a gene named ras after the rat sarcoma virus in which it was originally discovered. And at that point molecular biologists began to foresee the possibility of a genetics of human cancer based on mutants of a relatively small number of identified cellular genes.

But even at the height of the euphoria generated in scientific circles by these genuinely remarkable discoveries sagacious commentators were pointing out uncomfortable discrepancies between the laboratory picture of tumorigenesis and the real thing. ${ }^{4}$

In particular, though a single mutant gene is apparently sufficient to transform the cultured mouse cells, epidemiological analysis has made it clear that several independent mutations must be required to transform a normal human cell. The answer to this paradox is generally believed to lie in the nature of the cultured mouse cells-a cell line known as NIH 3T3, which is very far from normal and may well already have undergone most of the steps required for tumorigenesis. Indeed, the mutant ras gene extracted from the bladder carcinoma cells will not transform more nearly normal cells. A second weakness in the chain of evidence linking viral oncogenes with human cancer is that despite their precarious claim to normality the NIH 3T3 cells cannot be transformed by any of the other 14 odd oncogenes, against which the evidence has thus remained circumstantial.

Both of these embarrassing gaps in the oncogene story have now been plugged by a series of experiments, reported recently in Nature, ${ }^{56}$ that have begun to make the molecular biologists' 